\title{
Remembering the Forgotten Past: A Case Study of Bali's First Governor, Anak Agung Bagus Sutedja
}

\author{
I Nyoman Wijaya ${ }^{1}$ \\ Department of History, Faculty of Arts, Udayana University, Indonesia
}

\begin{abstract}
This article explores the way forgetting and remembering a dark past takes place in Balinese society. To do so, it takes the case of Anak Agung Bagus Sutedja, the first Governor of Bali, who was appointed in 1959 but 'disappeared' in 1965 or 1966 . He has been systematically forgotten by Balinese society and, more specifically, by and within the academic community of Udayana University. Applying a historical approach, this article argues that the process of forgetting in the community is deeply entangled with the New Order's embodied official narratives about the 1965 tragedy
\end{abstract}

Keywords: G30S, PKI, mass murder, memory, act of forgetting

\section{Introduction}

The Faculty of Medicine at Udayana University in Bali named two rooms after its founders on March 2, 2018. The meeting hall was named after dr. Anak Agung Made Djelantik, a lecturer and doctor who graduated from Gemente Universitet, the Netherlands, while the assembly room was named after Prof. dr. I Goesti Ngoerah Gde Ngoerah, who had served as the dean of the Faculty. It is here in which the interest of this paper lies.

These two men were central to the establishment of the Faculty of Medicine at Udayana University. However, one other figure is left: the chairman of the committee that prepared for Udayana University's establishment in 1962. This study asks why his leadership and founding role in the establishment of the university and the faculty of medicine have been forgotten by Balinese academia. This situation is believed to have taken place as part of the anti-communist purges that spread through Bali and Indonesia in 1965-1966. This paper takes the case of Sutedja as an entryway into an exploration of the means with which the Balinese deal with their haunting past.

In 1958, following the establishment of Bali as a province, Sutedja was directly appointed by President Sukarno

${ }^{1}$ Coresponding e-mail: iwijayastsp@yahoo.co.id 


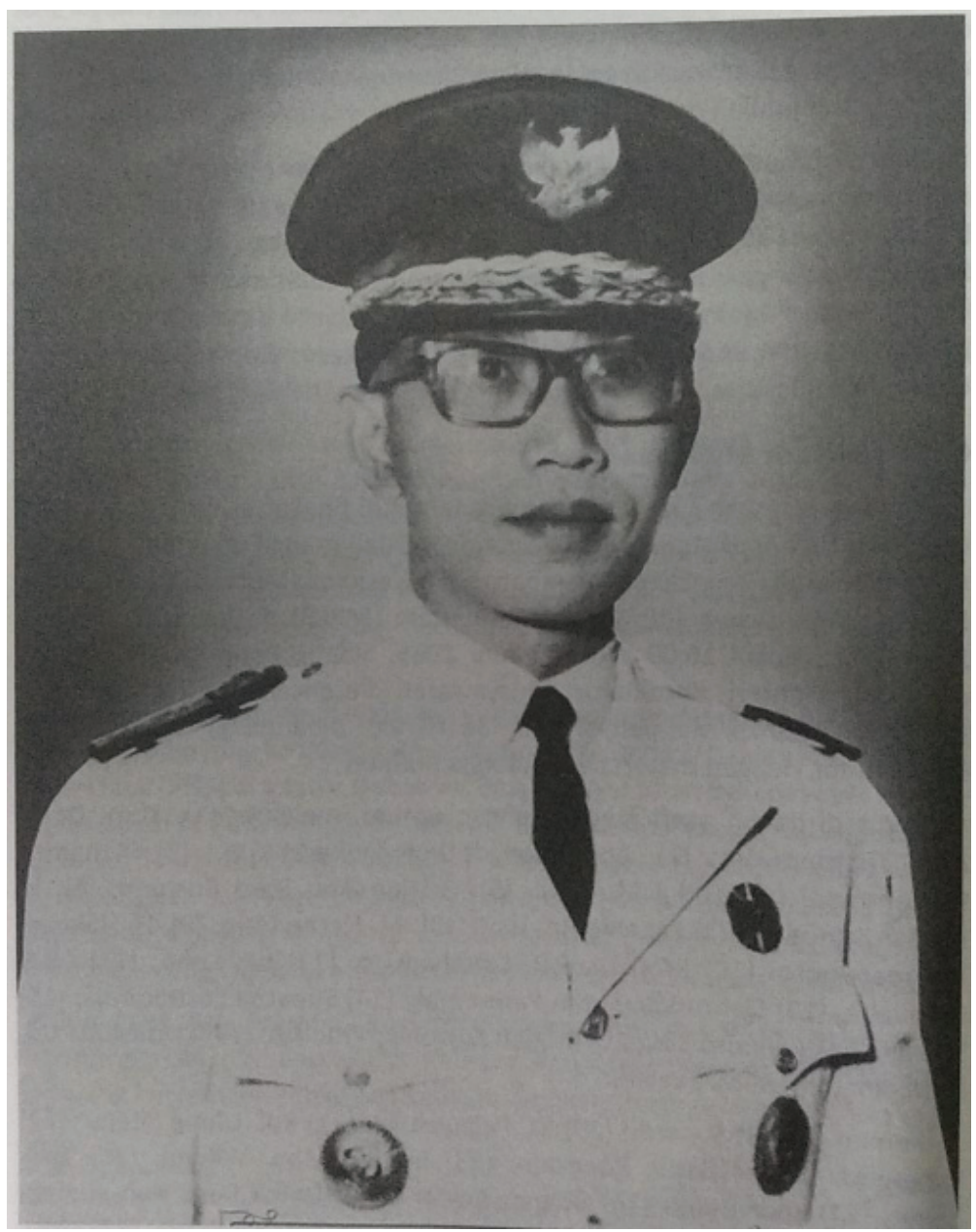

Figure 1. Image of Sutedja

(document A. A. G. A. Sutedja: Rekonsiliasi Terapan Supremasi Hukum dan Hak Azasi Manusia Gubernur Bali Anak Agung Bagus Sutedja, p. 2)

as the island's first governor. As such, he became a central figure in Balinese society. Among the developments under his administration was the establishment of a medical school on the island, for which he contacted Anak Agung Made Djelantik. Despite minimal preparation, the Faculty of Medicine at Udayana University was finally established in
1962. This was made possible in part by President Sukarno's support.

However, the university has no tribute to Sutedja, and indeed his name had previously been removed from Udayana University's Faculty of Letters (which has now been renamed Faculty of Arts). It should be noted, however, that this faculty existed long before the 
establishment of Udayana University, having grown out of a polemic between the Indonesian Socialist Party (PSI) and Indonesian Nationalist Party (PNI) regarding the removal of Balinese script and language lessons from elementary and junior/senior high schools. During the First Balinese Language Congress (held October 23-26, 1957), Sutedjachairman of the board of Transitional Government in Bali-ruled against the removal of the Balinese script and language from schools (Wijaya, 2012, p. 227). This decision led to the establishment of what is now the Faculty of Letters at Udayana University. Initially, the Foundation of Nusa Tenggara Faculties (YFNT) under Letnan Kolonel (Lieutenant Colonel) Minggoe, Commander of Infantry Regiment 26/ VII Wirabuwana, was tasked with determining the necessary preparations. Afterwards, Sutedja, I Gusti Putu Merta (Chairman of the Balinese House of Representatives), and some other political elites went to see Prijono (Minister of Education, Teaching, and Culture) in Jakarta to convey their plans (Nn, 1992).

YFTN then established the Preparatory Committee for Nusa Tenggara College (PPPTNT), which was responsible for finalizing the plan to establish the Faculty of Letters. This committee established networks with relevant people and agencies, and on September 29, 1958, the Faculty of Letters was established as a branch of Airlangga University, Surabaya. After the establishment of Udayana University on August 17, 1962, the faculty was integrated into the university. It should be noted, however, that Governor Sutedja has also been forgotten in the naming of the faculty's buildings and rooms.

\section{Literature Review}

I should be very clear that this current study has had difficulty collecting sufficient references on this topic. To date, no historians have seriously explored why Governor Sutedja has been forgotten in the naming of buildings/rooms at the faculties of medicine and literature at Udayana University. A very central reference is the study "Nasib Para Soekarnois: Kisah Penculikan Gubernur Bali, Sutedja, 1966" (The fate of the Sukarnoists: The story of the kidnapping of the Governor of Bali, Sutedja, 1966) by Aju, a senior journalist. According to his study, Sutedja was victimized 
and stigmatized as a member of the Indonesian Communist Party (PKI) after his political enemies claimed that he was a party member who had been involved in the failed 30 September Movement (G30S) coup attempt (Aju 2015). This story was spread quickly, and on December 1, 1965, Sutedja's house in Puri Negara, Jembrana, was looted and razed by a mob.

In developing his argument, Aju managed to provide evidence that Sutedja was not a PKI member. He wrote that, during the New Order period, Coordinating Minister of Politics and Security Soedomo was quoted in Tempo (dated 17 September 1988) as saying that Sutedja was not involved in the G30S coup. Furthermore, the Chairman of the Balinese House of Representatives, Col. (ret.) I Gusti Putu Raka-in his capacity as the Head of the Dwikora Implementation Authority (Pepelrada)-confirmed that there was no indication or evidence of Sutedja being directly or indirectly involved in G30S. On December 1, 1965, Soekarno had called for Sutedja to be reassigned to Jakarta. He was kidnapped there on July 29,1966 , and his final fate remains a historical mystery.

Slamat Trisila (2013), an alumnus of the Departement of History, Faculty of
Letters, Udayana University, published an essay on Sutedja. Similar to Balinese historians, he was also reluctant to openly discuss Sutedja's leadership as Governor of Bali. A similar standpoint was also taken by Widminarko (2013), a senior journalist who once studied at Faculty of Letters of Udayana University. In his essay, he discussed the mass action demanding Sutedja's resignation as Governor of Bali.

Meanwhile, I Ngurah Suryawan (2008), a graduate of the Department of Anthropology, Faculty of Letter of Udayana University, firmly asserted that Sutedja and his brother Anak Agung Bagus Denia had been PKI supporters. In his essay, Suryawan analyzed the violence that occurred in East Tegalbadeng in early October 1965. This violence, he claimed, involved the Army's Special Forces Unit (RPKAD) and tameng, young villagers trained by the army to slaughter PKI members. However, at that time RPKAD had yet to arrive in Bali, and no such story was published in Suara Indonesia, a local newspaper, in October 1965. Suryawan further argued that, sometime in October/November 1965, vandalism and riots occurred. Denia's house was burnt down, as was Governor Sutedja's 
house, which was located just next door. No such report can be found in Suara Indonesia's coverage from October 1 - November 31, 1965. Trisila (2013), meanwhile, stated that Sutedja's house was razed on 2 December 1965, a fact that can be verified through Suara Indonesia's coverage.

\section{Assumption and Question}

The above review of the literature indicates that Governor Sutedja was stigmatized as a PKI member and G30S supporter. The Indonesian government has officially confirmed that such claims are incorrect. During the Reformasi era, the government continued to provide moral support, confirming that Sutedja was not a PKI member and that he was not involved in G30S. This is evidenced, for example, by a ngaben (traditional cremation) ceremony conducted symbolically for Sutedja on July 23, 2006. This ceremony, aside from providing a symbolic last rite for Sutedja, marked the end of the 40-year search for him. During this traditional ceremony, a military ceremony was also conducted by members of the Veteran Legion under District Military Command 1617/Jembrana. Two days later, a mamukur ritual-a ceremony to provide spiritual purification for Sutedja-was performed. President Megawati Sukarnoputri was present, supporting Sutedja and his family.

Nonetheless, the present generation does not want to rehabilitate Sutedja's name, as seen in the actions of the faculties of medicine and literature at Udayana University. Overwhelmed by the collective memory that Governor Sutedja was a PKI member and involved in G30S, these faculties have seemingly held that he deserves to be forgotten. This assumption needs to be validated through an examination of how the Balinese community's collective memory of Governor Sutedja manifests itself.

\section{Theoretical Framework and Method}

The use of specific individuals' names for rooms/buildings at the faculties of medicine and arts of Udayana University indicates that these individuals are seen as having created something worth remembering. This results in artificial, rather than original, signifiers of the past. They refer to memories of the past, which may have changed or may vary significantly from 'what really happened' (Budiawan, 2013, p. vii). At these faculties, too, something is remembered and something is 
forgotten. The assigning of specific names to figures, remembering some and forgetting others, has shaped and been shaped by (Budiawan, 2013, pp. vii-viii) how the faculties' policymakers define their 'sense of collective self'. Remembering and forgetting may be two sides of the same 'coin' of memory, as they may change places. What was remembered can be forgotten, while what was forgotten may be remembered, depending on how the 'sense of self' is defined. As identity is relational, the definition of one's 'sense of self' depends on who or what is being imagined or faced as 'the others' and how one's relationship with 'the others' functions.

In this case, most Balinese still imagine 'the others' as those involved or accused of being involved in G30S; these 'others', they perceive, deserve exclusion. As such-again to borrow from Budiawan (2013, p. ix)-the memory (remembering and forgetting) of the persons behind the establishment of these two faculties is not purely a record of the past (i.e. individuals, mechanics, materials) or a causative logical framework of challenges and solutions. Rather, the practice of remembering and forgetting can be categorized as social constructions in a contextual and particular manner. As a social construct, the practice of remembering and forgetting Sutedja can be put within Halbwachs' framework as a relationship between individual and collective memory (see Budiawan 2013, p ix). The individual memories of persons and parties with the power to forget or remember the founders of the faculties cannot be separated from the collective memory of the mass killings that followed the G30S movement, which were either witnessed directly or heard from others. In other words, the memories of individuals cannot be isolated, since they always correspond with the collective entities in which they are located (see also Ikhwan, Yulianto, and Parahita 2019).

In parallel with the ongoing tension in Bali, there was broader regional and global chaos. Disappointed with the appointment of Malaysia as a member of the United Nations Security Council, Indonesia delivered its political statement and announced its intent to withdraw its membership from the United Nations (UN). On January 2, 1965, UN Secretary General U Thant sent a letter to President Soekarno urging him to reconsider his intention 
to withdraw from the United Nations. Soekarno, however, refused, and on January 7,1965 , at 10:35 p.m., Soekarno formally declared that Indonesia was leaving the organization ("Presiden Soekarno: Indonesia Positif Keluar dari PBB", 1965, p. 1) (See also Taylor 1965).

Public Gathering of the National Front (Badung Chapter)

On March 6, 1965, a day before Soekarno declared Indonesia's withdrawal from the United Nations, the Badung Chapter of the National Front held a public gathering at Puputan Badung Field, Denpasar. Wedastera Suyasa, chairman of the leadership council of Bali's PNI chapter, gave a speech. Initially talking about Indonesia's plan to withdraw from the United Nations, he suddenly changed the subject to the kidnapping and assault of a Front Marhaenis member in Jatiluwih, Tabanan. Sutedja immediately stepped onto the stage and stopped Wedastera Suyasa's speech, as it was deviating from the topic of the gathering. The gathered PNI supporters were disappointed, and they all left the field. Several days later, they staged a protest in front of Governor Sutedja's official residence ("Release Pds. Pangdak. Tentang Rapat
Umum Ganjang Nekolim," 1965, p. 1).

This incident was the climax of a series of events. By early 1964 , it was impossible for anybodyincluding organizations-to be neutral or independent of a political party. Workers who supported PNI joined the Marhaen Workers' Union (KBM), both at the provincial and district level. When they had different political affiliations, workers would still get along well, hoping that their political affiliations would not create splits. In society, however, intrigue and conflict were inevitable. Political sentiments often developed into personal sentiments, which could potentially transform into open conflict (interview with Ida Bagus Gede Soka, June 30, 2010).

Several parties intentionally took advantage of the political situation to promote the interests of themselves or their groups. The people they personally disliked were transformed into shared enemies, a process facilitated by fragmentation of society into political blocs. Exacerbated by personal sentiments and social inequalities, the situation deteriorated rapidly. Different parties sought to show their force through reciprocal actions, which were followed by unilateral actions, ultimately 
creating fear in society and threatening production activities (interview with Ida Bagus Gede Soka, June 30, 2010).

One such unilateral action took place in Penyaringan Village, Jembrana District, at the end of June 1964. Following some terror activities, various parties were forbidden from holding gatherings or events in the village. Except for members of the PKI committee, all agreed. PKI, meanwhile, held one activity-which lasted from June 27, 1964, until the next morning ("Awig-Awig Desa Penjaringan Diindjakindjak," 1964, p. 3). Another unilateral action took place in Sumberkima, Gerokgak, Buleleng. On October 12, 1964, at around 07:00 in the morning, 64 people-led by Wayan Kresti from Sendang, Setat Salin from Sumberkimia, and Subagio from Sumberklampokentered the offices of a plantation owned by Yayasan Kebaktian Pejuang (YKP) armed with sharp weapons such as sickles. These protestors climbed trees and picked coconuts. However, after the police fired warning shots, the protesters immediately ran to save themselves ("Demonstrasi Sarbupri-BTI di Perkebunan JKP Sendang," 1964, p. 2).

In this situation, people who desired unity and peace tended to agree with the Nasakom doctrine implemented by President Soekarno; by doing so, they sought to avoid siding with any specific political party. Certain political elites, however, preferred that everybody clearly showed their political affiliation. This can be seen from the following dialogue between Ida Bagus Gede Soka and I Gde Puger, a PKI donor.

"Gus, why did you join another party? You once joined our party. Now you are challenging your elder brother."

"Not really, bro. I did not join a party to create enemies. It was because I was entrusted with leadership of KBM, to ensure that it becomes a good organization, not a messy one."

After that event, Soka met Puger several times, and there was no hostility between them. Puger seemed to have understood Soka's position; he had to join KBM because the leader of the company for which he worked was a PNI member. As a friend, Puger whispered this piece of advice to him: "Please be careful. Our country is heating up." (interview with Ida Bagus Gede Soka, July 30, 2010).

As mentioned above, Gde Puger's caution was proven right during the public gathering of the Badung chapter of the National Front. At the event, all of the leaders of Nasakom-based political 
parties were given the opportunity to deliver a speech. During Wedastra Suyasa's speech, he mentioned the kidnapping and beating of a Front Marhaenis member in Jatiluwih, Tabanan, and also said that land, forests, and coffee plantations in Jatiluwih had been seized by Peasant Front of Indonesia (BTI) members. Why were they not defended? Governor Sutedja was furious. He immediately stepped up to the 3-meter podium, and the two men pushed each other (interview with I Gusti Made Sindu, Sanur, October 20, 2010).

I Gusti Made Sindu and Ida Bagus Gede Soka (the names of both informants are pseudonyms), who attended the meeting, could not explain further the incident in Jatiluwih. This incident took place on March 1, 1965, when some 100 PKI supporters led by Nang Rendang came to see Nang Janten. They beat, detained, and kidnapped Nang Janten and his family ("Krojok Tjulik \& Anjaja," 1965, p. 1). This incident traced its roots to a loan agreement between Nang Janten and Rampiyeg, which was made in January 1965. Under the terms of this agreement, everything produced by the land owned by Rampiyeg would be under Nang Janten's power for 30 years. However, along the way, Nang
Rampiyeg reclaimed his land without repaying the loan. For security's sake, Rampiyeg had ten BTI members guard the land ("Tindakan Apa Ini?," 1965, p. 3) Nang Janten and his wife were punched, kicked, and stoned; they were even cut with bladed weapons (“Tindakan Apa Ini?," 1965, p. 3). The BTI members threatened Nang Janten's life, saying he would only survive if he were willing to join PKI. However, he was saved by the police and members of Front Marhaenis. On behalf of PNI's leadership, the chairman of the party's Balinese chapter urged the military to investigate this case ("Krojok Tjulik \& Anjaja," 1965, p. I).

According to a press release by the Commander of the Balinese Police Force, the content of Wedastra Suyasa's speech deviated from the main topic, 'Indonesia's withdrawal from the United Nations.' As such, Governor Sutedja asked the resort commander and the prosecutor general to investigate Wedastra Suyasa. The National Front, meanwhile, was unwilling to accept Sutedja's actions, and all members walked out of the public meeting when Governor Sutedja was giving his speech ("Release Pds. Pangdak. Tentang Rapat Umum Ganjang Nekolim," 1965, p. 1). 
Approximately an hour and a half after the meeting, members of Front Marhaenis under the leadership of Wedastra Suyasa returned to the town square, where they staged a protest. Security officers on-site immediately took action, leading Governor Sutedja to his office north of the town square. They then gave Wedastra Suyasa the opportunity to voice his aspirations. Wedastra Suyasa delivered five important points in his speech, including that the Front Marhaenis obeyed the Pepelrada of Bali and that it felt upset about the incident ("Release Pds. Pangdak. Tentang Rapat Umum Ganjang Nekolim," 1965, p. 1).

The conflict between these political elites affected Balinese society. A group of people were soon spotted dragging an effigy of Malaysian Prime Minister Tengku Abdurrahman, which they burned. In response, Governor Sutedja forbade further protests and asked the police to detain Wedastra Suyasa. Members of PNI immediately protested his actions, issuing pamphlets and sending an open letter to the regional committee of the Balinese PKI branch. They also staged a counter protest, imitating the military exercises once conducted by PKI (Suweda, 1989, p. 103).
Wedastra Suyasa was arrested by the police on March 9, 1965, as instructed by Governor Sutedja in his capacity as Chairman of Pepelrada Bali ("Ditahan," 1965, p. 1). Shortly afterwards, a group of Marhaenis officials issued a petition protesting the arrest to Governor Sutedja (in his capacity as Chairman of Pepelrada Bali) and other relevant parties. Copies of the petition were sent to President Soekarno, the Minister of Domestic Affairs, and other parties ("Protes Keras," 1965, p. 1).

\section{Retooling Sutedja}

During counter protests, the cry "Retool Sutedja" was frequently heard. On March 11, 1965, PNI members held a meeting at the official residence of the Deputy Chairman of the Balinese House of Representatives (DPR-GR) on Jl. Melati to plan a movement to overthrow Sutedja. On the morning of March 12, 1965, members of PNI and the Front Marhaenis travelled from all over Bali to Ngurah Rai Stadium, Denpasar, before moving to the Governor's Office-one kilometer from the stadium-to stage a protest. By this time, the office was being guarded by Panca Tunggal and mass of PKI 
members. Nonetheless, the protest continued, with caustic remarks and hostile faces found throughout the crowd (Widminarko, 2013, pp. 123125).

As the political climate of Bali grew increasingly heated, on April 10, 1965, President Soekarno stated that he would deliver a speech before the Supreme Provisional People's Consultative Assembly (MPRS). This speech was intended to redirect the situation towards the revolutionary doctrine 'Standing on [Our] Own Feet' ('Berdiri di atas Kaki Sendiri', or Berdikari). Even before the speech, its influence-particularly a decrease in the price of textiles-was felt in Indonesia's major cities ("PedagangPedagang Textil Banting Stir Harga," 1965, p. 1).

Tensions in Bali reached their peak in 1965. I Made Parlemen, a member of Tameng Marhaenis from Panesan Village, Klungkung Palace, was killed in front of Klungkung Temple on May 20,1965, at around 10 p.m. local time ("Presiden Soekarno: Indonesia Positif Keluar dari PBB - Kita Sanggup Berdiri Sendiri," 1965). Members of PNI were terribly shocked, expressing their condolences in one local newspaper:
"Our condolences on the death of the beloved member of Tameng Marhaenism, Brother Parlemen, as a result of the terror from people who sought to uphold the law of the jungle on May 20 in the town of Klungkung. We march forward! One falls, a thousand grow! With the Marhaenism Declaration as its weapon, Marhaen will surely win" ("Belasungkawa Atas Gugurnya Tameng Marhenisme Kita Jang Tercinta," 1965, p. 4).

This expression of condolence called upon the "fighting" spirit of PNI's members. On the same day it was published, three BTI members were attacked by unidentified people in Kubutambahan, a village in Singaraja, North Bali (Suara Indonesia, June 9, 1965: p. 1). It was initially difficult for the police to find evidence and track the killers of I Made Parlemen. Nevertheless, in early June 1965, the Balinese police identified G. Tj as the killer, with five others as his accomplices. At nearly the same time, the perpetrators of the attack in Kubutambahan were also identified. This gave the impression that the state was able to protect the people (Suara Indonesia, June 9, 1965: p. 1).

From this discussion, it may be said that the most direct cause of the political violence that Governor Sutedja experienced was not, as indicated by Aju (Aju, 2015, pp. 15-16), Nyoman 
Mantik's disappointment at not being promoted as governor. According to Aju, in the 1958 plenary session of the Balinese House of Representatives, Nyoman Mantik defeated Sutedja in the gubernatorial election. Nevertheless, President Soekarno appointed Sutedja to a second term as Governor of Bali. Although this may have contributed to the violence, it was not the most direct cause. Rather, focus should be given to Wedastra's provocative actions described above, which led him to conflict with Governor Sutedja. During the Nasakom era, Sutedja was still in control of his political enemies. Things turned against him, however, after G30S.

\section{The End of Nasakom}

Effectively, the Nasakom doctrine lost all power after the killing of a group of generals on September 30,1965, by a group known as the 30 September Movement (G30S) or the October 1 Movement (Gestok). In the morning of October 1, 1965, G30S members occupied the headquarters of the Radio of the Indonesian Republic (RRI) in Jakarta and read a typed document on-air over the course of ten minutes. This document said that Lt. Col. Untung, the commander of the presidential guard, had moved to prevent a "counter revolutionary coup" by a group known as the Council of Generals (Dewan Jenderal). This group sought "to take measures against accomplices and supporters of the Council of Generals" (Rossa, 2008, pp. 52-53). Less than twelve hours later, the RRI station was retaken by Army Strategic Command (Kostrad) troops under the command of Maj. Gen. Suharto. The situation was seemingly reversed, and after the bodies of the slain generals were found and buried, propaganda calling for the destruction of the $\mathrm{PKI}-$ which was accused of having planned the coupbegan. This marked the beginning of Suharto's gradual erosion of Sukarno's power.

In Bali, 76 members of the Indonesian Armed Forces and civil servants at Military Command XVI Udayana were said to have been involved in G30S and were ultimately arrested ("Rumah Djl Kambodja D.60 Sarang G-30-S," 1965, p. 1). On October 27, 1965 , Brig. Gen. Sjafiudin-the highestranking military official in the regionestablished investigative teams at the provincial and regency levels. These teams were responsible for investigating 
all detainees, both military and civilian, and collecting the information and materials they needed to address the current situation ("Keputusan Pepelrada Bali Dalam Hadapi G30S," 1965, p. 1)

On November 1, 1965, at 8:45 pm, Governor Sutedja-in his capacity as Chairman of Pepelrada-decreed the establishment of a team, headed by Lt. Col. CKH I Gusti Putu Raka, that would investigate all detainees and prisoners ('Penguasa Pelaksana Dwikora Daerah Bali Surat Keputusan No: KEPPPD.2/1/231," 1965, p. 3). Sutedja also issued a decree that suspended all activities of organizations under the $\mathrm{PKI}$ umbrella, including the Concentration of Indonesian Student Movement (CGMI) and the Security and Defense Workers Union (SBKP) ("Penguasa Pelaksana Dwikora Daerah Bali Surat Keputusan No: KEP-PPD.2/1/231," 1965, p. 3).

On November 3, 1965, Sutedja issued another decree suspending the activities of mass and political organizations that were accused of being involved in G30S, including the Indonesian Communist Party (PKI), the Peasant Front of Indonesia (BTI), the Indonesian Women's Movement (Gerwani), and the People's Youth (PR). All political party and mass organization leaders were required to report to the local police and include their names on their boards or signs. This degree's implementation and enforcement were mandated to the Regional Police Commander for Bali ("Penguasa Pelaksana Dwikora Daerah Bali Surat Keputusan No: KEP-PPD.2/1/231," 1965, p. 1).

Also on November 3, 1965, Sutedja announced the implementation of curfew (lasting from 11 p.m. to 4 a.m.) in all parts of Bali, to remain effective from the date of the policy's issuance until its revocation ("Jam Malam di Bali," 1965, p. 2). The following day, a decree was issued requiring political party leaders to report to the relevant authorities (Suara Indonesia, 6 November 1965: 3).

\section{The Vandalizing of Sutedja's House}

In early December 1965, the political situation in Bali remained volatile. The Balinese House of Representatives (DPR-GR) had issued three decrees: (1) no longer acknowledging Sutedja as the Chairman of the Balinese House of Representatives; (2) urging Pepelrada Bali to take measures against Sutedja in accordance with Paragraph 6 of KOTI Instruction No. 22 of 1965; and (3) asking President Soekarno to dismiss 
Sutedja as Governor of Bali (“Gab. Seksi DPRD GR Bali Putuskan Tidak Akui A.A.B. Sutedja Ketua DPRGR," 1965, p. 1).

On December 2, 1965, Sutedja's home Puri Negara was vandalized. Trisila, quoting Jelantik and Suarja (sic) (2007) and Suryawan (2005 and 2007), writes that the event corresponded with the killing of a soldier. Suara Indonesia ("Rumah A.A.B Sutedja di Negara dan 'Ex. Pimpinan' PKI Hantjur," 1965, p. 1), meanwhile, identifies the incident as having been initiated by former members of $\mathrm{PKI}$ and its sub-organizations, an identification attributable to the party's perceived links with G30S. I Ngurah Suryawan (2008), finally, identifies the vandals as being a mob from Tegalcangkring and Penyaringan villages; he writes that this mob was led by two of PNI's leaders, Wedastra Suyasa and Widagda.

On December 4, 1965, Sutedja's leadership as Governor of Bali was questioned by the heads of provincial/ government departments in Bali ("Kepala Dinas/Djawatan Dati I Bali: Tidak Akui A.A.B. Sutedja Gub. Kdh. Bali," 1965, p. 1). At that time, however, Sutedja was not in Bali. According to Mansur Hidayat (1996, p. 81), as protests grew increasingly common, Sutedja escaped to Jakarta and was officially dismissed as the province's governor. However, Sutedja's trip to Jakarta was not an escape; rather, he had travelled to the capital on December 1, 1965, to attend several national events, including the joint session of the People's Consultative Assembly, the end-of-year session of the Supreme Advisory Council, the National Council Meeting of the ' 45 Generation, the session of the National Development Planning Assistance Forum, and the National Front Board Meeting (Sutedja, 2004, p. 8).

While in Jakarta, Sutedja lived at Jl. Renang 261-262, near Bung Karno Stadium in Senayan. On July 29, 1966, he was 'picked up' by four armed men in green uniforms to fulfill an 'invitation' from Captain Teddy at the Skogar Headquarters on Jl. Perwira, Central Jakarta. Sutedja has been missing ever since. Three military institutions-the Skogar Headquarters, the Military District Command, and the Jakarta Pepelrada-have given three different explanations: no instruction to 'pick up' Governor Sutedja was issued by the institution; the name 'Captain Teddy' was unknown and unregistered; and 
no 'Jeep Nissan' with the license plate number '04-88145' was registered in the institution's inventory of vehicles (Documentation of A.A.G.A. Sutedja 2004: pp. 8-9).

The Arrival of the Army ParaCommando Regiment

On December 7, 1965, after completing a tour of duty in East Java, the first soldiers from RPKAD and Brawijaya Division, East Java, landed in Bali; more soldiers arrived the following day. Everywhere they stopped, they said that $\mathrm{PKI}$ members were barbaric traitors and atheists who had explicitly provoked violence, and thus deserving reprisal (Robinson, 1995, p. 281).

\section{The Testimony of Faculty of Arts} Teaching Staff

The arrival of RPKAD troops gave new energy to parties and groups that considered themselves opposed to PKI. Killings were rampant. Persons who had been involved in various $\mathrm{PKI}$ activities, either in passing or as members/officials, were overwhelmed by fear. They felt frightened when evening came, not knowing when they would be targeted by tameng activists. As such, many sought protection from the influential people in their neighborhoods (Wijaya, 2012, p. 401).

Directly or indirectly, everyone was a witness of the event, including a number of students at the Faculty of Literature, Udayana University, who later became lecturers. This can be seen in the work of Sri Lestari (2016, pp. 234-235).

"Many people went missing. Kidnappings and killings happened everywhere. I was scared. However, nobody knew who kidnapped them and where they were killed. That was very complicated," as Jendra revealed.

"The same thing happened to the mass movements. Some killings happened. In the mass movements in Bali, maybe thousands of people from PKI died. BTI, Barisan Tani Indonesia, the Indonesian Peasant Front. The situation had been brought on by the PKI. Before the movement took place, it had been growing in Central Java. The earth was growing old. DN Aidit would be born. He was the head. He made the movement", according to Jendra.

Nobody wanted to be accused of being a PKI member, leading to many taking part in the killings:

"There was a killing in the village (Pejeng, Gianyar). My father, who was a PNI member, saw it. It happened in the field. My father was not involved in the killing; he only witnessed it as a PNI member. If he had not been there, he would have 
been accused of being involved in G30S," as Renik said.

The killing of people affiliated with $\mathrm{PKI}$ became the subject of conversation everywhere, including on campus, as mentioned by Jendra. He knew that a friend who was a member of CGMI-a student organization affiliated with PKI-had been killed at Jl. Bali, Denpasar, near the faculty campus. Indeed, Jendra himself wanted to kill that person and was waiting for him. He only later learned that the person had been killed, but he did not know who killed him, or where he was killed. Jendra did not see the killing; he only heard about it.

"It was very horrible. People kept killing each other. People affiliated with PKI were taken, sometimes from their homes. At my house, since I was PNI, they yelled at my parents. They stomped their feet in front of my house. That's true. There was a lot of killing. Balinese were killed, but this is kept a secret by the government, as if nothing happened" (Lestari, 2016, pp. 235-236).

Meanwhile, according to Jendra, the guilt or innocence of people on campus was frequently unclear. "A lot of Balinese went missing. I did not know many of my close friends' whereabouts. In the village, it was clear whether one was affiliated to PKI or not." This not only happened on campus, but in society as well. It was even common among government officials, such as Governor Sutedja.

Such individual memories were transmitted by the senior lecturers at the Faculty of Literature, Udayana University, to their students, some of whom became lecturers in turn. This has extended the process of forgetting figures allegedly involved in G30S, as seen in the writings of Mansur Hidayat (1996), I Ngurah Suryawan (2008), and Slamet Trisila (2013).

\section{Conclusion}

Despite talking about previously 'taboo' episodes in history being possible in the current era of Reformasi, this has not happened at the faculties of medicine and literature at Udayana University. To borrow a term from Budiawan (2013, p. xv), the memories of the policymakers at these two faculties seem to have been shaped by the writing of history, in which a certain ideologization has become embedded. These memories, ultimately, seem to have placed the former Governor of Bali, Sutedja, in a "seven-generation curse" akin to ancient Balinese tales of people being cursed for things they have not done. While other institutions 
of higher education, such as Gadjah Mada University in Yogyakarta, have gradually exposed the dark episodes of their pasts, Udayana University remains unmoved. We do not know until when.

\section{References}

Aju. (2015). Nasib Para Soekarnois: Kisah

Penculikan Gubernur Bali, Sutedja, 1966. Depok: Yayasan Penghayat Keadilan.

Awig-Awig Desa Penjaringan Diindjakindjak. (1964, October 16). Suara Indonesia.

Belasungkawa Atas Gugurnya Tameng Marhenisme Kita Jang Tercinta. (1965, May 25). Suara Indonesia.

Budiawan. (2013). Sejarah dan Memori Titik Samping dan Titik Temu, Yogyakarta: Ombak

Demonstrasi Sarbupri-BTI di

Perkebunan JKP Sendang. (1964, October 16). Suara Indonesia.

Ditahan. (1965, March 10). Suara Indonesia.

Dwyer, Leslie and Degung Santikarma 2007. "Posttraumatic Politics: Violence, Memory, and Biomedical Discourse in Bali." In Understanding Trauma, L. Kirmayer, R. Lemelson and M. Barad, eds. NY: Cambridge University Press.
Gab. Seksi DPRD GR Bali Putuskan Tidak Akui A.A.B. Sutedja Ketua DPRGR. (1965, December 2). Suara Indonesia.

Hidayat, M. (1996). Biografi Politik I Gusti Putu Merta. Denpasar: Udayana University.

Ikhwan, H., Yulianto, V. I., \& Parahita, G. D. (2019). The Contestation of Social Memory in the New Media: A case study of the 1965 killings in Indonesia. Austrian Journal of SouthEast Asian Studies, 12(1), 3-16. Indonesia Keluar dari PBB? Sekdjen U Thant dengan Sangat Minta Indo. Tetap Sebagai Anggota PBB. (1965, January 4). Suara Indonesia.

Jam Malam di Bali. (1965, November 3).

Suara Indonesia.

Kepala Dinas/Djawatan Dati I Bali:

Tidak Akui A.A.B. Sutedja Gub. Kdh. Bali. (1965, December 5). Suara Indonesia.

Keputusan Pepelrada Bali Dalam Hadapi G30S. (1965, November 1). Suara Indonesia.

Komando Daerah Angkatan Kepolisian XV Bali, Pengumuman: No. POL..:15/PENG/1965 (6 November 1965). Suara Indonesia.

Krojok Tjulik \& Anjaja. (1965, March 5).

Suara Indonesia. 
Lestari, S. (2016). Prosopografi Alumni

Fakultas Sastra Universitas Udaya Angkatan Pertengahan Tahun 1960-

an. Denpasar: Udayana University.

Nn. (1992). Pidato Pembukaan Fakultas

Sastra Udayana di Denpasar oleh

Menteri Pendidikan, Pengajaran, dan

Kebudajaan pada hari Senin tanggal

29 September 1958. Widya Pustaka, IX.

Pedagang-Pedagang Tekstil Banting Stir

Harga. (1965, April 4). Suara Indonesia.

Penguasa Pelaksana Dwikora Daerah

Bali Surat Keputusan No: KEPPPD.2/1/231. (1965, November 4).

Suara Indonesia.

Peristiwa Pembunuhan Parlemen

Terang, 6 Orang Terdakwa Ditahan

(9 Juni 1965). Suara Indonesia.

Presiden Soekarno: Indonesia Positif

Keluar dari PBB - Kita Sanggup

Berdiri Sendiri. (1965, January 9).

Suara Indonesia.

Protes Keras. (1965, March 10). Suara Indonesia.

Release Pds. Pangdak. Tentang Rapat

Umum Ganjang Nekolim. (1965, March 10). Suara Indonesia.

Robinson, G. B. (1995). The Dark Side of Paradise: Political Violence in Bali. United States: Cornell University Press.
Rossa, J. (2008). Dalih Pembunuhan Massal: Gerakan 30 September dan Kudeta Suharto. Denpasar: Udayana University.

Rumah A.A.B Sutedja di Negara dan "Ex. Pimpinan" PKI Hantjur. (1965, December 4). Suara Indonesia.

Rumah Djl Kambodja D.60 Sarang G-30-S. (1965, November 28). Suara Indonesia.

Suryawan, I. (2008). Bertutur Di Bali Senyap (Studi Antropologi Kekerasan Pembantaian Massal Tragedi 1965 Di Desa Tegalbadeng, Negara.

Sutedja, A. A. G. A. (2004). Rekonsiliasi Terapan Supremasi Hukum dan Hak Azasi Manusia Gubernur Bali Anak Agung Bagus Sutedja.

Suweda, A. A. N. K. (1989). Partai Nasional Indonesia (1950-1966).

Taylor, A. M.(1965): "Sukarno: The First United Nations Drop-Out", International Journal, Vol. 20, No. 2, pp. 206-213.

Tindakan Apa Ini? (1965, February 27).

Suara Indonesia.

Trisila, S. (2013). A.A.B Sutedja: Gubernur Bali Pertama dalam Lipatan Sejarah. Jurnal Kajian Bali, 03(1).

Widminarko. (2013). Mandiri Belajar Sendiri: Jejak Warga Bali Kelahiran Banyuwangi. Denpasar: Pustaka T. 
Wijaya, N. (2012). Menerobos Badai Biografi Intelektual Prof Dr. I Gusti Ngurah Bagus. Denpasar: Pustaka Larasan.
(2018). Bening Embun A.A.

Made Djelantik Putra Raja-DokterBudayawan. Denpasar. Denpasar: Pustaka Larasan. 